\title{
Niran, Judit. 2014. Jelek a vízen ('Signs on the Water'). Budapest: Libri. 260 pp. Illus.
}

\section{Reviewed by Ilana Rosen, Ben Gurion University of the Negev, Israel}

Judit Niran's Jelek a vízen ('Signs on the Water') is a professional, biographical and mental memoir written by a Budapest-born and presently Bar-Ilan University (Israel) ethnomusicologist, who -- back in the mid-1970s -- as a Hungarian Academy of Sciences ['Magyar Tudományos Akadémia'] disciple embarked on a study of the Hungarian-Jewish religious music of her time and place. Niran (née Frigyesi, 1954) soon found out that in order to understand this music she had to acquire a deeper and broader understanding of the lives of its practitioners as Jews of the old or inter-war world, as Holocaust survivors and as devout people striving to maintain their olden-days beliefs and practices in the world of communism. Moreover, knowing close to nothing about her own Jewish identity as about the Holocaust of Hungarian Jews, Niran now realized that her research entailed a deeply moving reconnaissance with her roots and family history. Niran's 1970s academic musicology studies, fieldwork among observant Orthodox Jews (mostly men and only rarely their wives), participation in services, meandering in the Budapest Jewish quarter and occasional leafing through prayer and other Jewish-wisdom books could not fill up the void of her non-acquaintance and alienation from the centuries-old tradition of her forefathers and foremothers; but all these efforts and endeavors did make her realize the depth of this void and enhanced her urge to know more about Jewish liturgy, the sole area of Jewish life she had recourse to as a trained musicologist. Or, to quote one of her poems in this book, she realized that at the end of her quest was none other than "herself of the life before her life" ['én voltam az, életem elötti életemben'] (13). In 1979 Niran emigrated to the United Sates and in 1998 she moved to Israel, but since 1989 and throughout the 1990s and 2000s she kept going back to Budapest, rarely meeting some of her 1970s informants, who were quickly dying out in those decades, and more often marveling at how the withering Jewish world she had known changed, partly disappeared and partly rejuvenated by American-Jewish newer acting souls.

Niran's book is divided into three chapters: "Voices behind the Thousand Walls" ['Hangok az ezer falak mögött'], "Lives" ['Életek'], and "Thorns and Flowers" ['Szilánkok és virágok']. Each chapter depicts a central aspect of the author's academic and mental exploration: the first, which holds two thirds of the entire book, is about her musical and personal revelations; the second presents, mostly verbatim, some of the life stories she recorded; and the third, which in fact serves as Conclusion to the book, revisits some of the experiences she acquired and the knowledge she gained in her Jewish-music project. Each chapter is further divided into sections resembling diary entries in their minute detailing of the places and people the author visited and of her thoughts and realizations on her project.

Niran's research project was initially sponsored by a German-Jewish donor whose name is not specified (this memoir is generally and probably intentionally non-academic in that it lacks details such as the full names of persons, most acutely those of all of her interviewees, captions accompanying their photos, and other bibliographic apparatus). She was also encouraged by

(cc) $\mathrm{Br}$

ULIS D-Serle
New articles in this journal are licensed under a Creative Commons Attribution 4.0 International License.

This journal is published by the University Library System of the University of Pittsburgh as part of its D-Scribe Digital Publishing Program and is cosponsored by the University of Pittsburgh Press 
Rosen, Ilana. "Niran, Judit. 2014. Jelek a vízen ('Signs on the Water'). Budapest: Libri. 260 pp. Illus.” Hungarian Cultural Studies. e-Journal of the American Hungarian Educators Association, Volume 9 (2016): http://ahea.pitt.edu DOI: $10.5195 /$ ahea.2016.240

leading musicologists of the time such as Bence Szabolcsi and Benjamin Rajecki (36), and later also by Judaism scholar Sándor Scheiber (38-39), as well as by world renowned conductor Charles Bruck, who happened to be her relative (87-101). In the process she learned about the salvaging projects of Avraham Zvi Idelsohn (1882-1938), a Latvian-born German-Jewish and later Israeli musicologist, who studied the musical traditions of Jewish diasporas and mainly those of Sephardic and Oriental or mizrahi communities; she could see similarities between Idelsohn's work and hers even though she was then unable to achieve his seminal study, Jewish Liturgy (New York: Holt and Co., 1932).

Niran first tried to interview a professional cantor but this encounter only made her realize that the real or authentic Jewish religious music was preserved not with professional stage-singers but with so-called everyday Jews whom she soon started meeting in synagogues or in their homes (40-41). These people, she now realized, might not know much about their performance as music in any professional terms but only, or rather, as part of their daily lives, prayers and conceptions. (Incidentally, in those very years, American-Jewish folklorist Barbara Kirshenblatt-Gimblett studied the storytelling performances of old-world East-European Jews as intervals between prayers, but Niran apparently confined her exploration to its musicology aspects only.) More specifically, and although this aspect of their worlds was often blended into their talks about tune and intention, Niran's elderly informants were lamenting the Hungarian Jewry that once was and that was lost in the Holocaust; which is why one such elder by the name of Zalmanovics told her that just as she sensed there was indeed sadness in Jewish prayer (234).

With time, as Niran spent more and more time listening to "her" elders or scrutinizing her recordings while making notes and diagrams on them (e.g., 61), she began to realize that her actual project was far from what she had imagined or what her instructors and advisors had thought of "Jewish music." To start with, the prayer melodies and chants, or zmiresz (Yid. 'zmires,' Heb. 'zmirot') she was recording were not strictly songs, as they could not be separated from the ritual of which they were part, which may explain the uneasiness she sensed on the part of some of her informants when she asked them to perform to her parts of prayer (see Emmanuel Waldman's evasive conduct and the jokes and stories he tells Niran in lieu of performing prayer parts to her, 44). In addition, in as much as these chants could be seen as songs, well, in most cases (excluding certain High Holidays prayers) they had no unique tunes; on the contrary, many past and present congregations occasionally replace/d and even borrow/ed popular tunes to enliven their services. One of Niran's informants, Viktor Feuerlicht, originally from Huszt (presently in Western Ukraine), told her at length how in the past, in the turn of the nineteenth and twentieth century, composers and musicians would come up before the New Year High Holidays with new melodies offering their music to congregation-leader rabbis, and the rabbis would pick what they liked. And anyway, says Feuerlicht, the tune is meant for the enjoyment of the audience joining the singing at the right place and time and thus enabling the cantor or prayer-leader ['elöimádkozó,' Yid. 'báltfile,' Heb. 'baal tefila' or 'shliah tsibbur' (75)] to rest a bit (140-141; for more on the soloist-choir dialogic dynamics of Jewish prayer see Niran's bookevent and interview by Ágnes Heller at Másolatt bookstore, Budapest, on April 30, 2015, at: https://www.youtube.com/watch?v=VI--t8wHuyg).

Niran then started studying Jewish liturgical music for what it really was in the eyes of its flesh-and-blood performers. The fruit of this phase in her work in general and in this memoir specifically is no less than a phenomenological (i.e., as experienced and conceived by its live practitioners) performative-poetics of Hungarian-Jewish prayer-music of the mid twentieth- 
Rosen, Ilana. "Niran, Judit. 2014. Jelek a vízen ('Signs on the Water'). Budapest: Libri. 260 pp. Illus.” Hungarian Cultural Studies. e-Journal of the American Hungarian Educators Association, Volume 9 (2016): http://ahea.pitt.edu DOI: $10.5195 /$ ahea.2016.240

century. Niran first of all noticed that much unlike the orderly and harmonic choir-singing she had previously encountered in her other musicology projects, e.g., the singing of Hungarian rural women $(128-9,138,144)$, the Jewish prayer sounds multi-vocal or polyphonic, disorderly and informal $(15,135)$. Yet, it does have rules that stem from earlier phases in the life of the Jewish people, when not everyone had a written text before them or could read, so those who had texts and could read did so in the name of their community as a whole. Therefore, pronunciation is important (50), although the author sometimes "complained" about the difference between the written Hebrew and the Yiddishized accent of her informants $(59,62$; in truth their accent was also Hungarianized but this evaded her as then a non-Hebrew and non-Yiddish speaker). For the purposes of clarity and precision, as Niran explains in her interview with Heller, although observant people may know many prayers by heart it is not acceptable to cite prayers by heart but only from the prayer book, to avoid mistakes or distraction. Then there is a whole division into text portions, so that some of them are read aloud, some are sung and some are performed as a dialogue between the prayer-leader and the audience; also, some prayers are to be read quietly, in murmur, each person to her/himself, which makes -- as Niran explains in her book event -- the praying person more deeply aware of her/his own voice, expression and personal prayer. A central informant of Niran's, Jenő Roth, originally of Hajdúnánás in North-East Hungary, supplied her with a touching oral so-called manual, wherein three elements of prayer interact to create just the right effect and affect on the praying individual and congregation. These include the act of prayer (Yid. 'dávenen'), the tune or melody (Yid. 'niszech,' Heb. 'nusah'), and the meaning or intention(ality) of prayer as internalized and expressed by the praying person/s (Yid. 'kavonesz,' Heb. 'kavanot') (73-77).

The prose of Niran's book is compelling in its own right for its special blend of learned and literary language, professional and personal (and at times familial) revelations, original imagery and synaesthetic (i.e., appealing to many senses at once) descriptions, like her "seeing" the Saturday morning prayer as light-blue and golden, and the late-afternoon prayer as dark blue and $\operatorname{dim}$ (135). Often, the connecting element or hinge between this performative-poetics of Hungarian-Jewish prayer and Niran's unique physical-sensual-spiritual embodied cognition (on which see: Margaret Wilson, "Six Views of Embodied Cognition," Psychonomic Bulletin and Review 9.4 [2002], 625-636, at:

http://www.indiana.edu/ cogdev/labwork/WilsonSixViewsofEmbodiedCog.pdf) of it is space as Niran experienced it in the decaying 1970s Jewish quarter of Budapest or on her later fieldwork excursion to a Prague synagogue. The synagogue's space is where the sounds of prayer spread and then resound to the praying people $(95,121)$; this space also turns the praying people into one entity, the congregation (159). Lastly, this communal space enables its users to exist as if out of time (143); although rabbis and Judaism scholars say that since the ruin of the Holy Temple (around the year $70 \mathrm{AD}$ ), prayer and other life-cycle and year-cycle practices have become the Jews' so-called Temples in time (on Jewish conceptions of ritual and other communal spaces see: Anna Lipphardt, Julia Brauch and Alexandra Nocke, Eds., Jewish Topographies - Visions of Space, Traditions of Place; Hampshire, England and Burlington, Vermont: Ashgate, 2008).

Judit Niran's lively and sensual memoir of her Jewish-prayer research-project in Budapest of the 1970s and later is a moving and inspirational work written in capturing poetic-prose. It is all the more admirable because, as the author repeatedly states in the book as in her book-event, she remained an outsider to the world of Jewish prayer and faith, like a businessman visiting the synagogue once a year on Yom Kippur, the Day of Atonement. To this reviewer, who happens to 
be an active member and vocal performer in a Conservative (Heb. Masorti) Movement Israeli congregation, it seems that to explore Jewish prayer-music while somehow avoiding the realization that this is all or primarily about religion (including theology, ethics and ethos, all mediated through powerful texts), not music, is somewhat like studying sports cheerleader dance and song as if they were all about performance and not about basketball or whichever teamballgame. But Niran manages to convince her readers that such a separation is possible, or rather that it all depends upon how one defines the goal of one's quest; and Niran's quest greatly fits her disposition as a second-generation to the Holocaust closeted Jew educated under the 1950s1070s Hungarian communism. Being, in addition, a multi-dimensional artist, Niran presents in her book dozens of black-and-white photos she made of yards and interiors of Budapest synagogues and other buildings, as well as of treetops with the sky positioned as background "underneath" them from the viewer's point of view (a seven minutes video of Niran's exhibition of these photos at the Budapest Ateliers Pro Art Galleries is found at:

https://www.youtube.com/watch?v=iTVagS4cQXc); yet, had at least some of these images been in color, the entire visual side of this rich, multi-genre and multi-media work would have been even more compelling. But even in its modest garb Judit Niran's Jelek a vizen offers its readers a gripping experience albeit not a light-hearted, merry one. 